\title{
Antena Wideband Planar Bowtie untuk Pemanenan Energi Gelombang Televisi Elektromagnetik Terestrial
}

\author{
Hanalde Andre \\ Jurusan Teknik Elektro, Fakultas Teknik, Universitas Andalas \\ Corresponding author e-mail: hanalde.andre@eng.unand.a.cid
}

\begin{abstract}
Abstrak - Proses pemanenan energi elektromagnetik memiliki dua aspek penting yaitu antena sebagai pengumpul gelombang elektromagnetik dan penyearah. Pada jurnal ini didisain antena bidang kupu-kupu yang dapat beroperasi pada frekuensi penyiaran televisi terestrial. Perancangan antena dilakukan menggunakan simulasi metode elemen hingga. Berdasarkan hasil simulasi didapatakan bandwitdh fraktional antena untuk nilai return loss dibawah $-10 \mathrm{~dB}$ sebesar 70,46\% dan bandwitdh fraktional antena untuk nilai VSWR dibawah 2 sebesar 75,98. Frekunsi tengah antena didapatkan sebesar $589 \mathrm{MHz}$.
\end{abstract}

\section{Kata Kunci : Pemanenan Energi, Elektromagnetik, Antena, Televisi Terestrial}

\begin{abstract}
The process of harvesting electromagnetic energy has two important aspects, namely the antenna as a collector of electromagnetic waves and rectifiers. This paper aims to design a planar bowtie antenna that can operate on terrestrial television broadcasting frequency. Design of antennas using finite element simulation method. Based on the simulation result, the bandwitdh fraktional antenna for return loss value below $-10 \mathrm{~dB}$ is $70,46 \%$ and fractionall bandwitdh antenna for VSWR below value 2 is 75,98 . The middle frequency of the antenna is $589 \mathrm{MHz}$.
\end{abstract}

Keywords : Harvesting Energy, Electromagnetic, Antenna, Terrestrial Television

\section{Pendahuluan}

Penggunaan gelombang elektromagnetik umumnya digunakan dalam media informasi elektronik seperti televisi, radio, telepon seluler, komunikasi nirkabel, satelit dan lain sebagainya. Seluruh gelombang elektromagnetik tersebut umumnya diradiasikan memiliki daya dengan kerapatan yang rendah.

Frekuensi yang digunakan untuk siaran televisi terestrial berada pada band Ultra High Frequency (UHF) dalam rentang $478-806 \mathrm{MHz}$ pada saluran 22 hingga 62 . Tidak semua saluran dapat digunakan dalam suatu daerah dikarenakan adanya interferensi untuk saluran yang berdekatan dan kebutuhan saluran untuk daerah yang bersebelahan. Ibukota provinsi mendapatkan alokasi saluran lebih banyak dibandingan dengan daerah lain [1]-[2].

Pemanfaatan elektromagenetik sebagai sumber energi listrik telah banyak dikembangkan oleh para peneliti. Hal ini didukung oleh semakin majunya teknologi semikonduktor dan efisiensi penggunaan daya pada perangkat teknologi [3][5]. Aplikasi teknologi ini dapat menyatukan pengiriman informasi dan energi ke perangakat dalam satu media sehingga meningkatkan efisiensi sistem.

Proses pemanenan energi atau harvesting energy elektromgnetik ditentukan oleh dua aspek penting: antena (pengumpul gelombang elektrogmnetik) dan rectifier (penyearah). Antena yang akan digunakan harus sesuai dengan frekuensi gelombang elektromagnetik yang akan dikumpulkan [6]-[8]. Keluaran antena merupakan arus listrik dengan frekuensi tinggi yang selanjutnya akan disearahakan dengan menggunakan rectifier.

Salah satu jenis antena yang memiliki karakteristik bandwith lebar adalah bentuk kupukupu atau bowtie. Bentuk antena ini merupakan pengembangan dari antena dipole yang memiliki karakteristik bandwith sempit atau narrow [9][11]. Jenis antena ini memiliki parameter sudut atau flare angle yang mempengaruhi karakteristik bandwitdh antena. 


\section{Tinjauan Pustaka}

Karakteristik antena sangat dipengaruhi oleh bentuk antena. Dimensi antena akan sangat berhubungan dengan frekuensi kerja. Semakin tinggi frekuensi kerja antena maka dimensi antena akan semakin kecil. Hal ini berhubungan dengan panjang gelombang elektromagnetik, sesuai dengan persamaan (1).

$$
\lambda=c / f
$$

Dimana,

$\mathrm{c}=$ kecepatan cahaya $\left(3 \times 10^{8} \mathrm{~m} / \mathrm{s}\right)$

$\mathrm{f}=$ frekuensi (hertz)

$\lambda=$ panjang gelomnga (meter)

Antena kupu-kupu atau bowtie memiliki karakteristik pita lebar. Karaketeristik pita lebar ini dipengaruhi oleh sudut atau flare angle. Semakin besar sudut flare angle akan menghasilkan bandwitdh yang lebih lebar. Parameter lain yang terdapat pada antena bowtie adalah radius dan gap. Kedua parameter ini akan mempengaruhi karakteristik frekuensi tengan antena. Panjang efektif antena didapatkan dengan menjumlahkan kedua radius antena dengan gap.

Pada gambar 1 dapat dilihat rancangan antena bidang dipole untuk frekuensi siaran televisi terestrial. Ls adalah panjang substrate. Ws adalah lebar substratr. Ra adalah radius antena. F1 adalah flare angle 1 dan F2 adalah flare angle 2. Dimensi antena dapat dilihat pada tabel 1. Panjang efektif antena setelah dijumlahkan dengan gap adalah sebesar $175 \mathrm{~mm}$ dan lebar antena adalah 164,2 $\mathrm{mm}$. Rasio panjang efektif antena dengan frekuensi tengah antena adalah sebesar 34,38\%. Nilai ini mendekati sepermepat panjang gelombang frekuensi tengah.

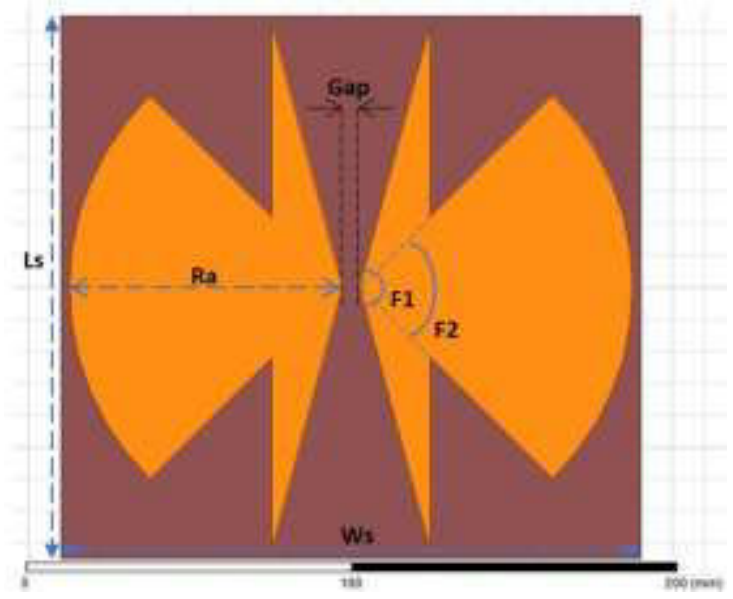

Gambar 1. Rancangan Antena
Tabel 1. Dimensi Rancangan Antena

\begin{tabular}{|c|c|}
\hline Parameter & Unit \\
\hline Ls & $180 \mathrm{~mm}$ \\
Ws & $170 \mathrm{~mm}$ \\
$\mathrm{Ra}$ & $85 \mathrm{~mm}$ \\
F1 & $150^{\circ}$ \\
F2 & $90^{\circ}$ \\
Gap & $5 \mathrm{~mm}$ \\
\hline
\end{tabular}

\section{Metoda}

Bagian ini akan membahas mengenai langkah - langkah penelitian yang dilakukan.

\subsection{Software Simulasi}

Peracangan antena dilakukan dengan melakukan simulasi menggunakan software Ansys Software (Ansoft) HFSS 15. Metode yang digunakan dalam simulasi adalah metode elemen hingga (Finite Element Method). Pada metode ini suatu objek dibagi menjadi beberapa bagian dalam jumlah yang terbatas. Proses pembagian tersebut disebut dengan meshing. Bentuk geometri antena dapat dilihat pada gambar 2 .

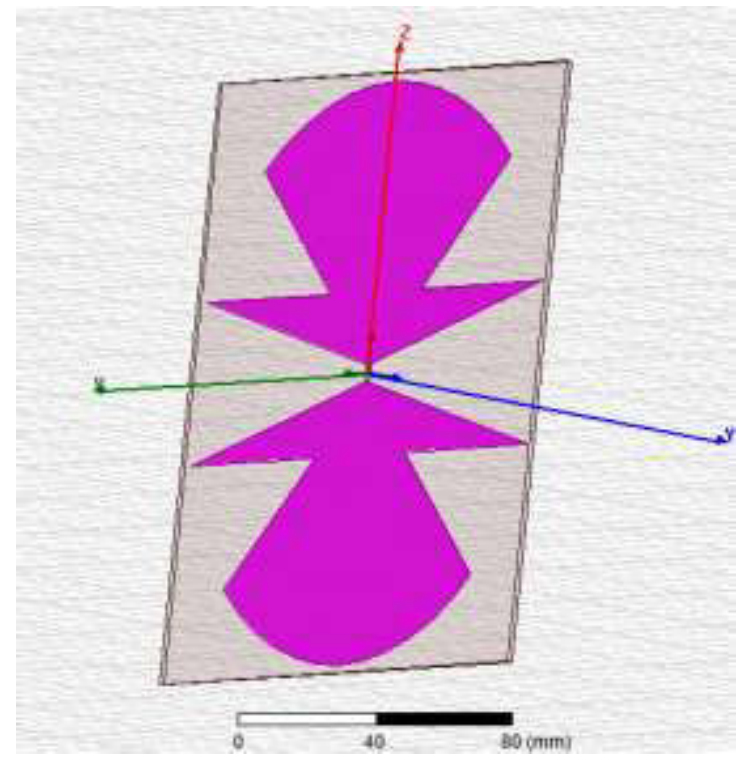

Gambar 2. Geometri Simulasi Antena

\subsection{Parameter Simulasi}

Menentukan parameter simulasi yang tepat sangat mempengaruhi keakuratan hasil simulasi. Pada gambar 3 dapat dilihat pengaturan solusi simulasi. Solusi frekuensi yang digunakan adalah sebesar $639 \mathrm{MHz}$. Nilai ini didapatkan dari frekuensi tengah penyiaran televisi terestrial pada 
rentang $478-806 \mathrm{MHz}$. sesuai dengan perhitungan berdasarkan pada persamaan (2). Penentuan nilai frekueni tengah ini sangat penting untuk mendapatkan hasil simulasi yang akurat.

$$
f_{c}=\frac{f_{u}-f_{l}}{2}
$$

Dimana,

$\mathrm{fc}=$ Frekuensi tengah

$\mathrm{fu}=$ Frekuensi atas atau tinggi

$\mathrm{fl}=$ Frekuensi bawah atau rendah

Jumlah maksimum siklus yang dilakukan dalam pengaturan nilai maximum number of passes. Dalam siklus tersebut nilai maksimum delta $\mathrm{S}$ ditetapkan sebesar $2 \%$ atau 0,02 .

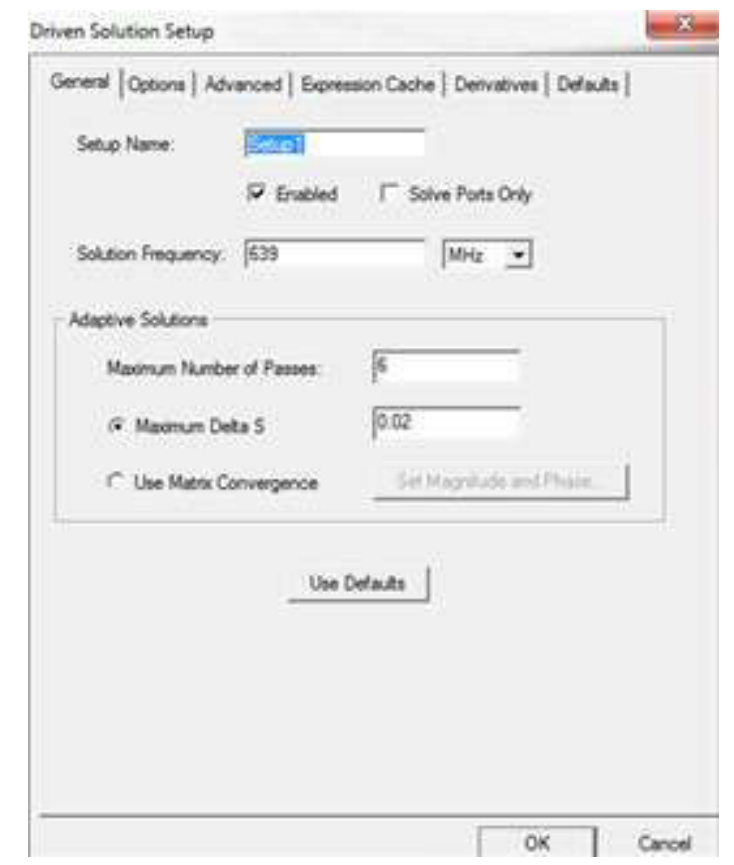

Gambar 3. Pengaturan Solusi Simulasi

Gambar 4 menunjukan pengaturan frequency sweep simulasi yang berada pada rentang 300 $\mathrm{MHz}$ hingga $1 \mathrm{GHz}$. Interval yang digunakan sebesar $1 \mathrm{MHz}$, maka didapatkan jumlah titik frekuensi yang dihitung sebanyak 701 buah titik. Jenis interval yang digunakan adalah linear sehingga jarak interval untuk setiap titik tetap. Jenis sweep adalah discrete sehingga nilai medan radiasi untuk setiap frekuensi dianalisa.

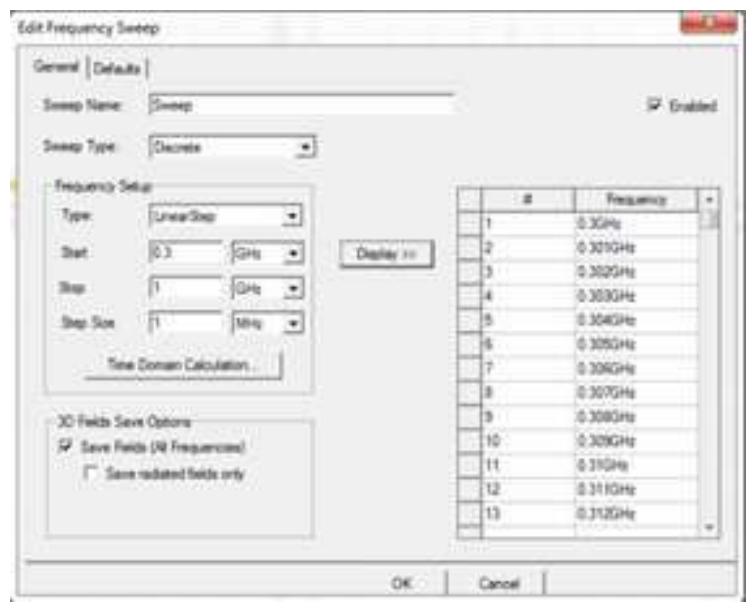

Gambar 4. Pengaturan Frequency Sweep Simulasi

Pengaturan daerah radiasi antena dapat dilihat pada gambar 5. Nilai phi dimulai pada 0 derajat hingga 360 derajat dengan interval 10 derajat sedangkan nilai theta dimulai dari 0 derajat hingga 180 derajat dengan interval 10 derajat. Pengaturan ini diperlukan untuk melihat karakteritik pola radiasi antena. Dalam simulasi medan radiasi antena berbentuk kotak dengan dimensi $180 \mathrm{~mm}$ X $190 \mathrm{~mm}$ x $500 \mathrm{~mm}$. Nilai ini sesuai dengan seperempat panjang gelombang frekuensi minimum dalam frequency sweep.

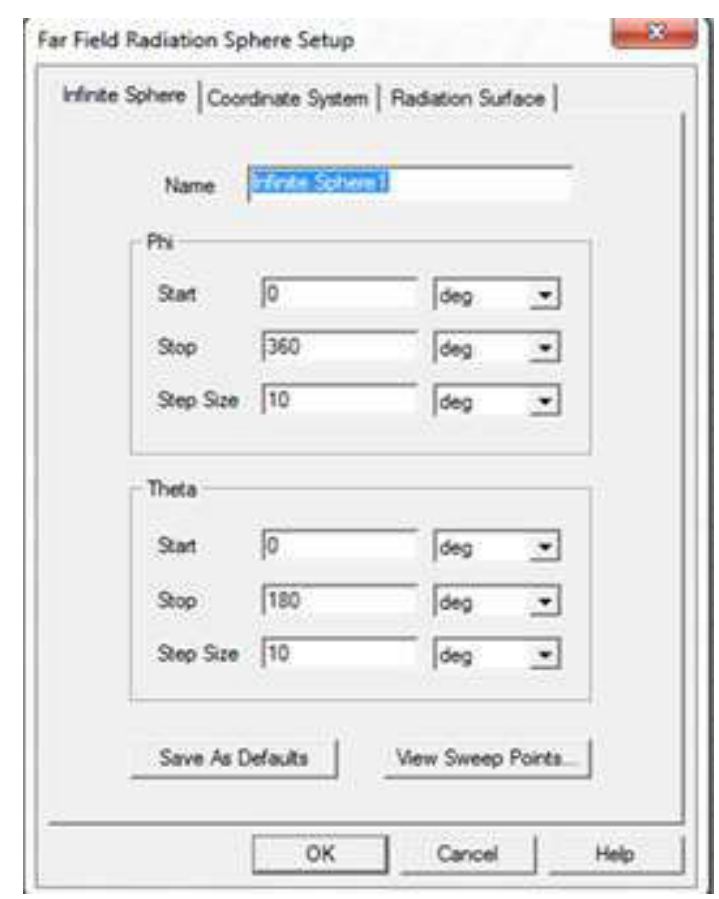

Gambar 5. Pengaturan daerah radiasi antenna 
Saluran pencatuan atau port antena diletakan pada ujung antena. Jenis port yang digunakan adalah lumped port dengan resistansi $50 \mathrm{ohm}$ dan reaktansi $0 \mathrm{ohm}$. Pengaturan port antena dapat dilihat pada gambar 6 . Nilai ini sesuai dengan nilai impedansi konektor dan saluran yang umumnya digunakan.

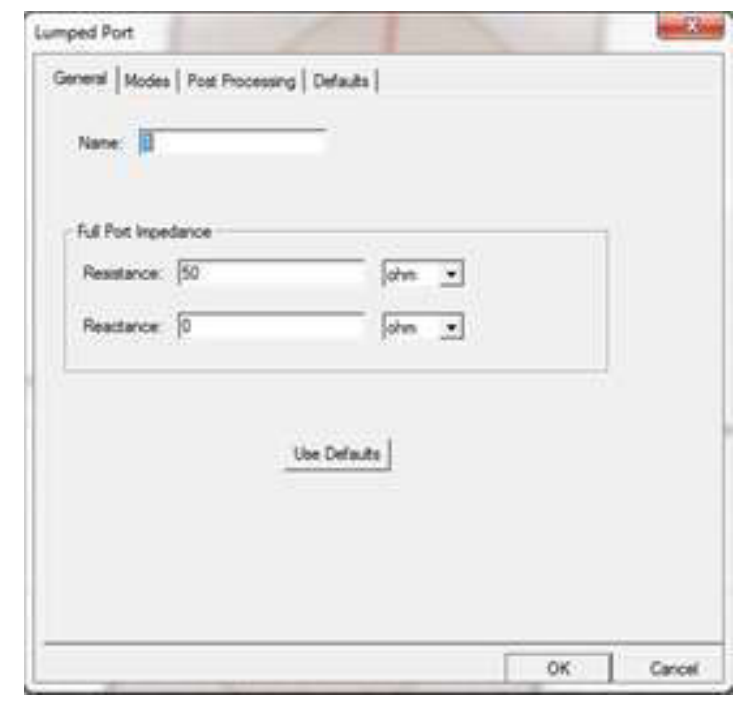

Gambar 6. Pengaturan Port Antena

\section{Hasil dan Pembahasan}

Antena yang telah dirancang memiliki bandwitdh dengan nilai RL dibawah $-10 \mathrm{~dB}$ sebesar $415 \mathrm{MHz}$. Bandwitdh tersebut berada dalam rentang 429,8 Mhz hingga 844,8 $\mathrm{MHz}$. Fractional bandwith dapat dihitung dengan menggunakan persamaan (3)

$B_{f}=\frac{f_{u}-f_{l}}{f_{c}} \times 100 \%$
Dimana,

$$
\begin{aligned}
\mathrm{B}_{\mathrm{f}} & =\text { Fraktional Bandwitdh } \\
\mathrm{f}_{\mathrm{u}} & =\text { Frekuensi Tinggi } \\
\mathrm{f}_{\mathrm{l}} & =\text { Frekuensi Rendah } \\
\mathrm{f}_{\mathrm{c}} & =\text { Frekuensi Tengah }
\end{aligned}
$$

Berdasarkan perhitungan menggunakan persamaan, fraktional bandwith antena didapatkan sebesar 70,46 \%. Dengan menggunakan perhitungan yang sama didapatkan fraktional bandwitdh untuk nilai VSWR dengan nilai di bawah 2 sebesar 75,98\%. Bandwitdh tersebut terletak pada frekuensi $412,9 \mathrm{MHz}$ hingga 860,4 MHz, frekuensi tengah yang didapatkan sama dengan nilai yang didapatkan pada perhitungan return loss.

Hasil simulasi nilai return loss antena dapat dilihat pada gambar 7. Nilai minimum return loss didapatkan pada frekuensi $589 \mathrm{MHz}$ sebesar $24,3288 \mathrm{~dB}$. Untuk nilai VSWR terbaik adalah 1,1294 pada frekuensi yang sama dengan nilai minimum return loss. Hasil simulasi nili VSWR antena dapat dilihat pada gambar 8. Dibandingkan dengan lebar efektif antena sebesar $170 \mathrm{~mm}$ didapatkan hubungan antara panjang gelombang frekuensi tengah antena dengan lebar efektif antena sebesar 0,288 .

Pada Gambar 9 dapat dilihat hasil simulasi gain rancangan antena. Gain antena merupakan perbandingan daya yang diterima atau dikirim suatu antena dengan antena isotropik. Berdasarkan hasil simulasi antena didapatkan gain antena pada frekuensi kerja minimum pada frekuensi 429,8 Mhz sebesar -3,26 dB dan pada frekuensi kerja maksimum pada frekuensi 844,8 Mhz sebesar 0,751 dB. 


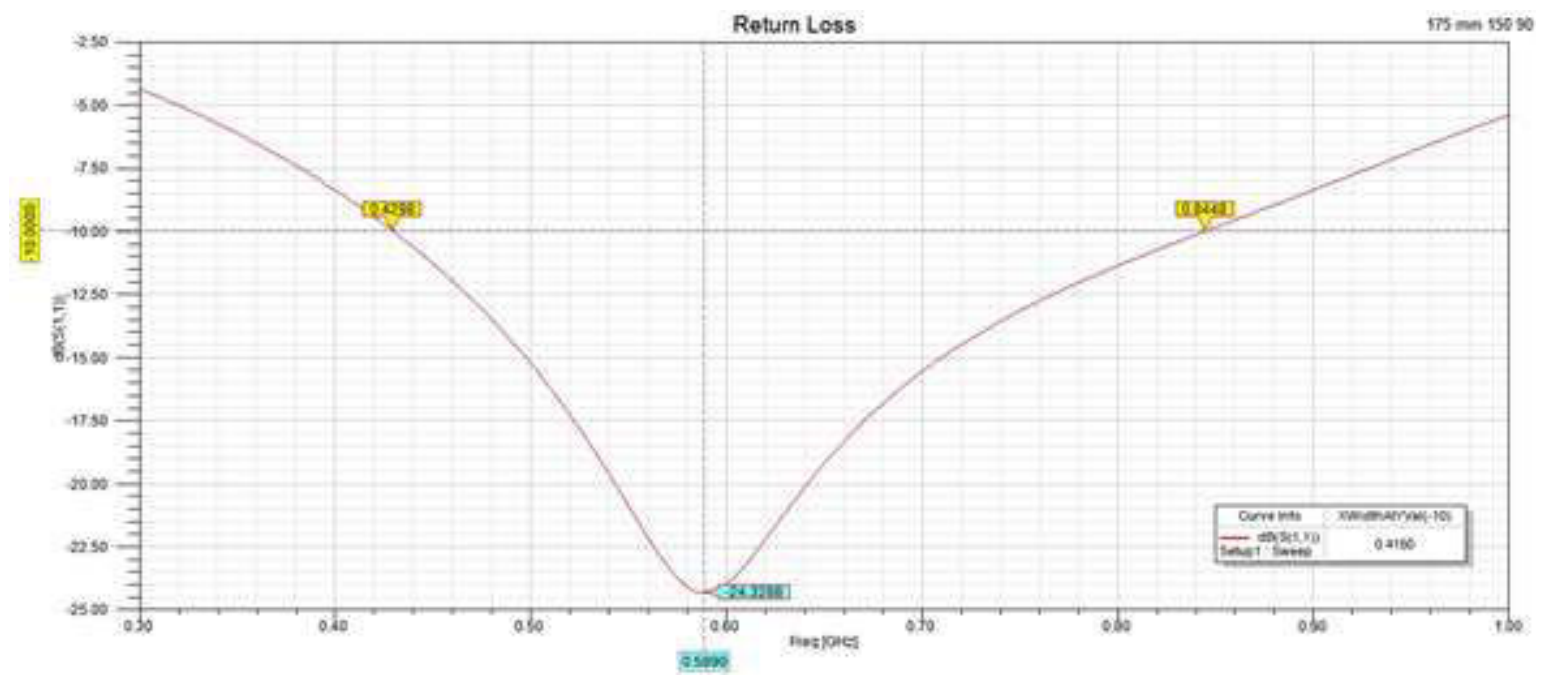

Gambar 7. Hasil Simulasi Return Loss Antena

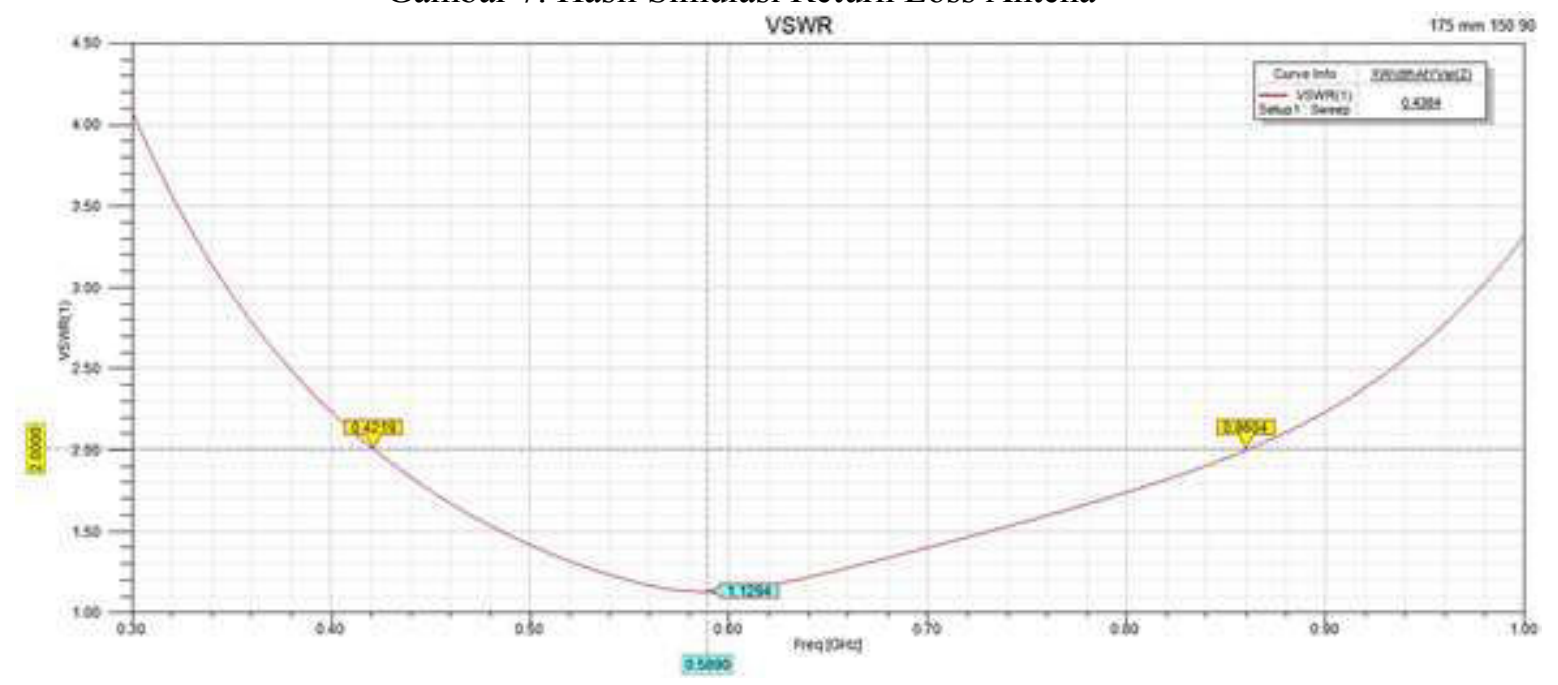

Gambar 8. Hasil Simulasi VSWR Antena

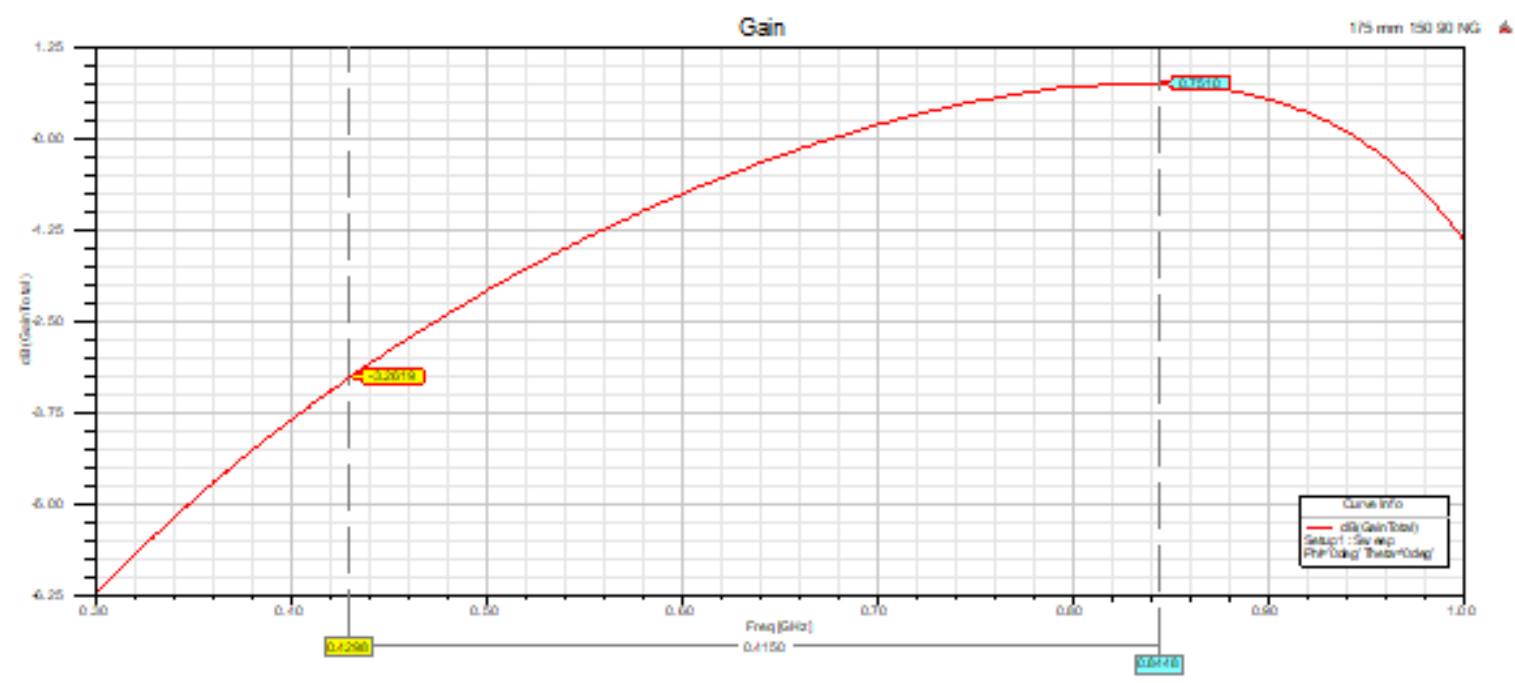

Gambar 9. Hasil Simulasi Gain Rancangan Antena 
Antena memiliki pola radiasi yang menunjukan sebaran pancaran gelombang elektromagnetik yang diterima tau dikirimkan. Pola radiasi adalah penggambaran pancaran energi antena sebagai fungsi koordinasi ruang. Pola radiasi dibentuk dari pancaran medan jauh pada antena. Pancaran yang dimaksud adalah intesitas medan listrik. Pada gambar 10 dapat dilihat hasil simulasi pola radiasi rancangan antena dalam bentuk tiga dimensi. Pola radiasi yang didapatkan rancangan antena sama dengan pola radiasi yang dimiliki oleh antena dipole yaitu pola radiasi yang bersifat omnidirectional.

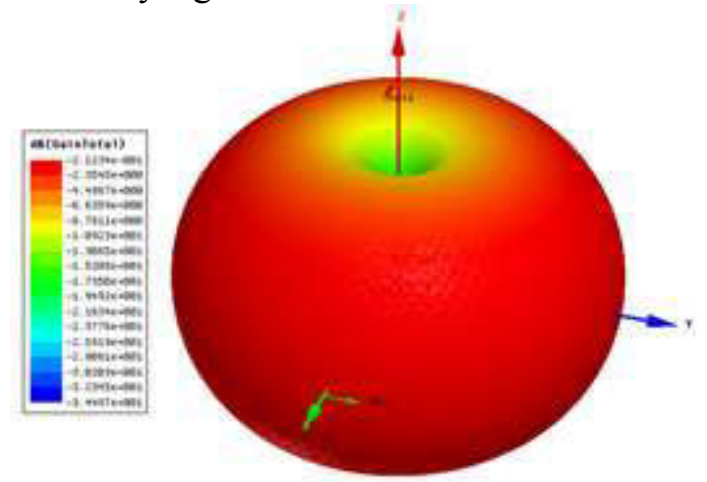

Gambar 10. Hasil Simulasi Pola Radiasi Rancangan Antena dalam 3D

Distibusi medan listrik rancangan antena sesuai dengan hasil simulasi dapat dilihat pada gambar 11. Dari gambar dapat dilihat medan listrik yang dihasilkan antena lebih besar pada ujung antena yang dekat dengan saluran pencatuan dan bagian sebelah kiri antena memiliki intensitas yang lebih besar dibandingkan dengan sisi antena sebelah kanan. Bagian antena dengan medan listrik tinggi memiliki nilai mendekati $200 \mathrm{~V} / \mathrm{m}$.

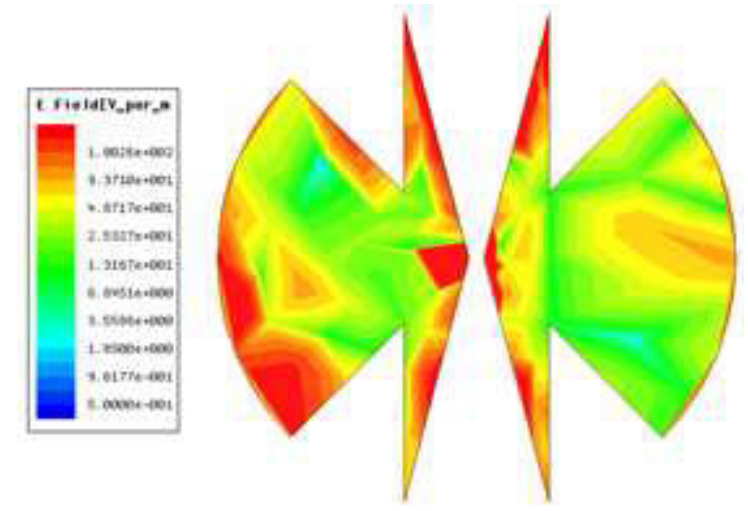

Gambar 11. Hasil Simulasi Distribusi Medan Listrik Rancangan Antena
Pada gambar 12 dapat dilihat hasil simulasi distribusi arus rancangan antena. pola distribusi arus pada rancangan antena terpusat pada ujung antena dekat dengan saluran pencatuan. Intensitas arus pada daeah tersebut mencapai $10 \mathrm{~A} / \mathrm{m}$.

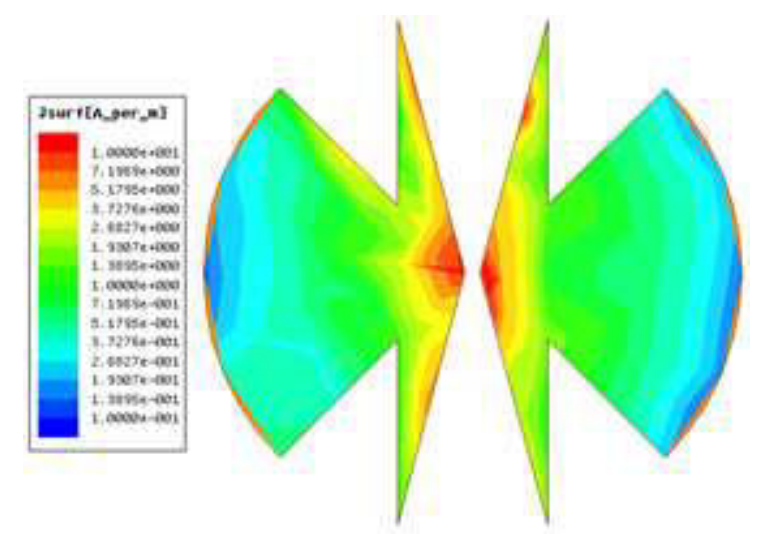

Gambar 12. Gambar . Hasil Simulasi Distribusi Arus Rancangan Antena

Pola radiasi rancangan antena berdasarkan simulasi dapat dilihat pada gambar 12 untuk pola radiasi penguatan (gain) dan gambar 13 untu pola radiasi keterarahan (directivity) antena. Hasil simulasi tersebut didapatkan untuk frekuensi 639 Mhz dengan sudut phi sebesar 90 derajat. Hasil simulasi menunjukan pola radiasi antena bentuk pola radiasi dalam sudut theta. Jenis pola radiasi yang dihasilkan sama dengan pola radiasi yang dihasilkan antena dipole. Hal ini dikaren rancangan antena adalh pengembangan antena dipole.

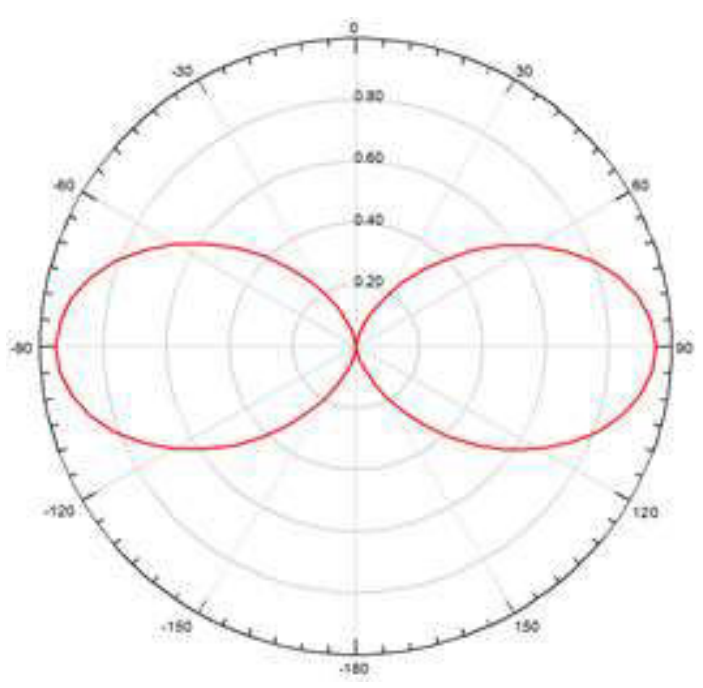

Gambar 12. Hasil Simulasi Pola Radiasi Gain Antena 


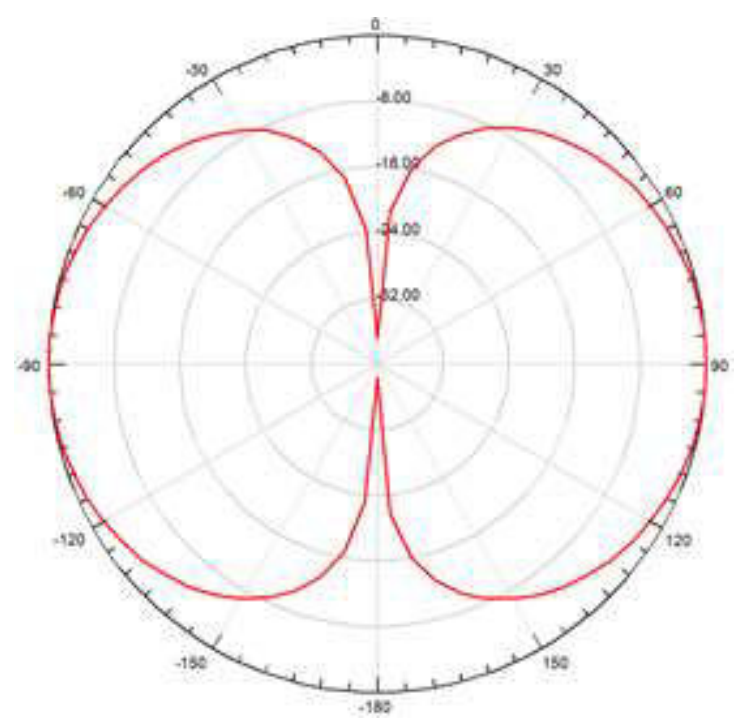

Gambar 13. Hasil Simulasi Pola Radiasi Directivity Antena

\section{Kesimpulan}

Rancangan antena mampu beroperasi pada frekuensi penyiaran televisi terestrial. Frekuensi kerja antena berada pada frekuensi $429,8 \mathrm{MHz}$ hingga 844,8 Mhz untuk performansi nilai return loss dibawah $-10 \mathrm{~dB}$. Untuk performansi antena dengan nilai VSWR dibawah dua didapatkan rentang frekuensi kerja antena yang sedikit lebih besar pada rentang 421,9 MHz hingga 860,4 Mhz. Pola radiasi yang disahilkan rancangan antena memiliki jenis yang sama dengan pola radiasi antena dipole yaitu omnidirectional. Distribusi medan listrik dan kerapatan arus antena berdasarkan simulasi memiliki intensitas yang tinggi pada ujung antena.

\section{Ucapan Terima Kasih (Acknowledgement)}

Penelitian ini didukung oleh Dana Penelitian Dosen Jurusan Teknik Elektro, Fakultas Teknik, Universitas Andalas dengan nomor kontrak 097/UN.16.09.D/PL/2017

\section{Daftar Pustaka}

[1] Andre, Hanalde., "Analisa Path Loss Spektrum Frekuensi UHF Untuk Penyiaran TV Terestrial Kota Padang”. Jurnal Nasional Teknik Elektro (JNTE) Universitas Andalas (UNAND), Vol: 6, No. 1, Maret 2017.

[2] P. SANJOY, "Digital Video Distribution in Broadband" in Television Mobile and
Converged Networks: Trends Challenges and Solutions, Wiley, pp. 384, 2010.

[3] Changjiang Deng; et.al., "A Wideband Isotropic Radiated Planar Antenna Using Sequential Rotated L-Shaped Monopoles," IEEE Transactions on Antennas and Propagation, vol.62, no.3, pp.1461,1464, March 2014

[4] Vincetti, L.; Maini, M.; Pinotti, E.; Larcher, L.; Scorcioni, S.; Bertacchini, A.; Grossi, D.; Tacchini, A., "Broadband printed antenna for radio frequency energy harvesting," ICEAA, 2012 , vol., no., pp.814,816, 2-7 Sept. 2012

[5] Scorcioni, S.; Larcher, L.; Bertacchini, A.; Vincetti, L.; Maini, M., "An integrated RF energy harvester for UHF wireless powering applications," IEEE Wireless Power Transfer (WPT), 2013 , vol., no., pp.92,95, 15-16 May 2013

[6] Shoichi Kitazawa, Hiroshi Ban, and Kiyoshi Kobayashi, "Energy harvesting from ambient RF sources", Proc. 2012 IEEE MTT-S Int. Microw. Workshop Series on Innovative Wireless Power Transmission: Technologies, Systems, and Applications, THU-B-2, pp. 39-42, Kyoto, Japan, May 2012.

[7] Shoichi Kitazawa, Hirokazu Kamoda, Hiroshi Ban, Naoya Kukutsu, and Kiyoshi Kobayashi, "Energy Harvesting from Broadcasting and Cellular Radio Sources", IEICE Technical Recport, WPT2013-16, pp. 49-54, November 2013 (in Japanese).

[8] V. Marian, B. Allard, C. Vollaire and J. Verdier, "Strategy for Microwave Energy Harvesting From Ambient Field or a Feeding Source", in IEEE Transactions on Power Electronics, vol. 27, no. 11, pp. 4481-4491, Nov. 2012.

[9] Andre, Hanalde., Khayam, Umar., "Antena Kupu-kupu sebagai sensor Ultra High Frekuensi (UHF) untuk Mendeteksi Partial Discharge pada Gas Insulation Substation". Jurnal Nasional Teknik Elektro (JNTE) Universitas Andalas (UNAND), Vol: 2, No. 2, September 2013.

[10] R. Persico, N. Romano, F. Soldovieri, "Design Of A Balun For A Bowtie Antenna Inreconfigurable Ground Penetrating Adarsystems", Progress In Electromagnetics Research [C], vol. 18, pp. 123-135, 2011. 
[11] H. Andre, U. Khayam, "Design of New Shape Printed Bowtie Antena for Ultra High Frequency Partial Discharge Sensor in Gas-Insulated Substations", IEEE, 2013

\section{Biodata Penulis}

Hanalde Andre, menyelesaikan S1 di Teknik Elektro Universitas Andalas pada tahun 2011, S2 Teknik Elektro double degree UNAND - ITB tahun 2013. Sekarang sebagai dosen di Jurusan Teknik Elektro Fakultas Teknik Universitas Andalas. Bidang keahlian adalah teknik telekomunikasi 